\title{
A Preliminary Study on Avian Fauna at Govt. (Model, Autonomous) Holkar Science College, Indore, (M.P.)
}

\author{
Osho Bhonsle ${ }^{1}$, C.S. Shrivastava ${ }^{2}$, Renu Jain ${ }^{3}$ and S. Gaherwal ${ }^{* 4}$ \\ ${ }^{1}$ Dept. of Zoology, Govt. (Model, Autonomous) Holkar Science College, Indore, India \\ 2 Dept. of Zoology, Govt. College Mundi, Dist. Khandwa, India \\ ${ }^{3}$ Dept. of Zoology, Govt. (Model, Autonomous) Holkar Science College, Indore, India \\ ${ }^{4 *}$ Dept. of Zoology, Govt. (Model, Autonomous) Holkar Science College, Indore, India \\ *Corresponding Author: psgaherwal@yahoo.com, Tel.:+91-9827247048
}

Available online at: www.isroset.org

Received 06/Jan/2018, Revised 19/Jan/2018, Accepted 11/Feb/2018, Online 28/Feb/2018

\begin{abstract}
In the present study carried out at the Govt. (Model, Autonomous) Holkar Science Campus, total 51 species of birds belonging to 14 Orders and 33 Families were recorded. Out of these 51 species, 41 species were found to be resident and 10 species were winter visitors. Only one species i.e. Alexandrine parakeet was found to be in the Near Threatened Category (NT) of IUCN. Interestingly, 13 new species of birds which were previously unrecorded at the college campus were recorded, which suggests the variation in the number of species and their abundance within the past years. Total 17 species of birds were recorded breeding inside the college campus. Their nesting preference and the use of anthropogenic material for building the nest was also studied. The results of Relative Diversity (RD) Index shows that the Family Muscicapidae $(\mathrm{RD}$ Value $=13.7)$ was dominant in the college campus. Seasonal variation was observed in few resident bird species suggesting their local movement. Further, the importance of large trees with dense foliage has been described and the negative impact of stray dogs on the life of birds is also discussed.
\end{abstract}

Keywords: Avian fauna, Resident bird, Winter visitors, Relative diversity index and Seasonal Variation.

\section{INTRODUCTION}

"Birds are feathered, warm-blooded, biped, vertebrate organisms" [1]. They are one of the most prominent species on the earth. They are the bio-indicators which can be used to access the health of any ecosystem, as they are highly sensitive to any unfavorable environmental change [2]. Hence, they are the key elements of any ecosystem [3]. Birds play an important role in any ecosystem as they are also potential pollinators, seed-dispersers and scavengers and are also beneficial to humans in agriculture by checking the population of harmful pests which adversely affect productivity [4]. The number of migratory birds visiting any area also indicate the health of that particular environment [5].

Urban habitats in the form of parks, gardens, or green spaces have been recognized as important elements in the cities. They are not only meant for human recreation but also support a large population of various life forms including birds [6,7]. Many researchers have concluded that urban habitats, though are species rich, are less species diverse. The major urban population of birds is either in the large green parks or in areas with more mature trees [8]. Studies have also found that the birds are usually richer towards the periphery than the center of the city [9]. Urban landscapes, though may be less species diverse, play a crucial role in supporting biodiversity as they are "Species Abundant Zones" [10].

The landscape of Indore city consists of a broad spectrum environment ranging from the city greens to highly modified artificial landscapes in some parts. The study site, Holkar science college is located on the southern part of the city and has a lush green campus with mature trees. A study was carried out at the college campus in 2004 with an aim to identify the avian fauna present in the campus [11]. We have thoroughly reviewed the previous literature on birds at the Govt. Holkar Science College campus and have not encountered any major studies that have been conducted since 2004. Hence, the present study was conducted with an aim to prepare a checklist of bird species found at the college campus and it also includes the study of seasonal variation, breeding and migratory status of birds. The selected site is expected to have species variation within these years. Thus, based on this study, the ecological health of the college campus can be determined.

\section{MATERIALS AND METHODS}

Study Area-The present study was carried out at Govt. (Model, Autonomous) Holkar Science College, Indore. It has 
a lush green campus and was established on $10^{\text {th }}$ June 1891 by Maharaja Shivaji Rao Holkar in Navlakha area. It has a huge area of 36 acres (15ha). The campus is lush green with more than 14 gardens and has many departmental blocks, surrounded by trees, majority of which are shrubs, short plants and grasses which provide a variety of food for birds. The important trees in the college campus are Mango (Mangiferaindica), Banyan tree (Ficusbenghalensis), Gular (fig) (Ficusracemosa), Amaltas (Cassia tora), Ashok (Polyalthialongifolia), Ber (Ziziphusjujuba) etc. [12].

Materials- The birds were observed using binocular and photographs were taken wherever possible. The identification of the birds was done by $[1,13,14]$.

Methods- To study the avifauna of the selected site, monthly observations were conducted from January 2016 to December 2016. At least 5 faunistic surveys were done in each month at an interval of 5-6 days for identifying the bird species. Observations and sighting records of birds were taken from the whole campus. Bird species were recorded and identified based on sighting, photographs and calls. Surveys were done by trekking on a fixed track roads going through the campus. The bird species were recorded using Time Species Count Method which was used twice in 2 hours. One from starting point of the track to the end point (1 Hour) and again from the end point of the track to the starting point (1 Hour). In Timed species count method, 10 minute series were made, totaling up to 6 Series in an hour [15]. The following formula was used to determine the percent of occurrence of families or relative diversity of families [16].

$$
\text { Relative diversity }=\frac{\text { No. of Species of each family }}{\text { Total no. of different species seen }} \times 100
$$

\section{RESULTS AND DISCUSSION}

In the present study, total 51 species of birds belonging to 14 Orders and 33 Families were recorded. Out of these 51 species, 41 species were found to be resident and 10 species were winter visitors (Table: 1). As these 10 species of migratory birds were only recorded during the winter season they were designated as winter migratory birds as studied by [17]. One species, Alexandrine parakeet was found to be in the Near Threatened category of IUCN (International Union for Conservation of Nature) $[18,19]$.

Similar observations were made by [11] at the Holkar Science College campus, Indore, where 51 species of birds belonging to 29 families were recorded. Although, out of the 51 species recorded by them, only 38 species were recorded in the present study. Rest of the 13 species of birds which were not recorded from the college campus during the study period are Little cormorant, Little egret, Black-winged stilt, Common sandpiper, Spotted dove, Indian roller, Barn swallow, Brahminy starling, House crow, Black-headed cuckoo-shrike, Indian bay-backed shrike, Common babbler and Brown chiffchaff. Interestingly, 13 new species of birds, which were previously unrecorded on the college campus, were seen during the present study and are Indian peafowl, Cattle egret, Alexandrine parakeet, Ashy drongo, Greyheaded canary flycatcher, White-breasted waterhen, Dusky crag-martin, Jungle babbler, Taiga flycatcher, White-spotted fantail flycatcher, Lesser whitethroat warbler, Greenish warbler and Sulphur-bellied warbler. The Common tailor bird, previously described to be uncommon and to be a winter visitor as per studies by [11], was found to be a resident bird and was recorded throughout the year in the present observation. Similarly, the Green bee-eater which was found to be common and to be a resident bird in their studies, was seen to be absent in summer and rainy seasons in the present study, suggesting its local movements. This observation however may need corroboration with yearly comparative studies. Tickell's blue flycatcher was also recorded, but rarely, in the winter season in the present study, whereas it was a common resident bird in their studies. Thick-billed Flowerpecker and Tickell's Flowerpecker were seen throughout the year on the campus, though it was uncommon in the studies of [11]. The review of above literature suggests that there is a variation in the number of species and their abundance within these 12 years at the Holkar science college campus.

The order Passeriformes was found to be dominant with 32 species in the present study (Fig: 1), which is also reported by $[11,20,21,22,23]$. In the present study from the selected site, Family Muscicapidae was found to be very rich with the highest relative diversity $(\mathrm{RD})$ index $(\mathrm{RD}$ value $=13.7)$ as shown in (Fig: 3). [11, 19, 24, 25] also found the Family Muscicapidae to be dominant in their studies. Red-vented bulbul, Blue Rock pigeon, Common tailorbird, Ashy prinia, Rose-ringed parakeet, Little brown dove, Purple sunbird, Jungle babbler, Coppersmith barbet and Red-wattled lapwing were found to be the most common birds during the present study as were also found in the studies of [3, 16, 21, 26, 27]. On the other hand, Ashy drongo and Tickell's blue flycatcher were recorded only a few times [26].

A total of 17 species of birds belonging to 7 Orders and 13 Families were found breeding in the college campus (Table: 2 ). The breeding of birds was recorded based on following characteristics such as Nests (also bird incubating or chicks seen in the nest), juveniles, birds carrying nesting material, parent bird carrying food in the beak for young ones and bird seen mating. The number of breeding species are the chief indicators of good health of any environment and the selected sites seem to be in good health [2]. The College campus has old mature trees bearing natural cavities which provide nesting places for hole nesting birds such as Oriental magpie robin, Rose-ringed parakeet and Coppersmith Barbet [28, 29]. Raptors prefer tall mature trees to make nests (Table: 3 ), $[30,31]$. Therefore, as the campus has large, tall and mature 
trees both the raptor species were found breeding at the Govt. Holkar Science College Campus. These species used Eucalyptus trees to make the nest, which also shows their preference for the tree over other trees [32, 33.] Interestingly, during the present study the Black kite was seen using artificial nesting materials such as rope, cloth and plastic string along with natural materials. It is estimated that a lack of nest building material, forces them to use such materials. Similarly, the Jungle babbler was also seen using a plastic string in its nest. Such use of anthropogenic materials for building nests in urban areas was also recorded by [28, 34].

Some of the resident birds were recorded only in specific seasons suggesting their local movements [35, 36]. Present observation of the Cattle egret during the rainy season, which showed its complete absence from the Holkar Science College Campus correlates well with the prior observations by [37]. Earlier observations of [11], found the Indian pond heron at the Holkar Science College Campus to be resident and common, however as per the present observation it was not recorded in the winter season. This finding of season specificity corroborated well with the prior studies of [38]. Finding of present work shows the decrease in frequency of the Rose-ringed parakeet during the winter season correlates with the similar findings by [27].

During the summer season, there was a minor change in the number of species at the college campus which doesn't have a permanent water source, whereas during the rainy season there was a gradual decrease in the number of resident species (Fig: 4). The reason behind the slight variation in the number of species at the college campus is the presence of tall, large, mature and leafy trees which provide shelter for the birds during the hot summer days. Hence, the presence of large trees with dense foliage is also important for the birds to thrive during hot sunny days along with other resources.

Occasional hunting incidents of Red-wattled lapwing chicks by stray dogs were seen at the Holkar Science college campus. These stray dogs were also considered as threats by $[39,40]$.

Table 1: List of Avian fauna recorded at the Govt. Holkar Science College Campus during the study period in Indore region.

\begin{tabular}{|c|c|c|c|c|}
\hline S. No. & Order/Family/Common Name & Scientific Name & $\mathbf{R S}$ & $\begin{array}{r}\text { IUCN } \\
\text { Status }\end{array}$ \\
\hline & $\begin{array}{l}\text { Order- Ciconiiformes } \\
\text { Family- Ardeidae }\end{array}$ & & & \\
\hline 1 & Indian Pond Heron & Ardeola grayii & $\mathrm{R}$ & LC \\
\hline \multirow[t]{2}{*}{2} & Cattle Egret & Bubulcus ibis & $\mathrm{R}$ & LC \\
\hline & $\begin{array}{l}\text { Order-Accipitriformes } \\
\text { Family- Accipitridae }\end{array}$ & & & \\
\hline 3 & Black Kite & Milvus migrans & $\mathrm{R}$ & LC \\
\hline \multirow[t]{2}{*}{4} & Shikra & Accipiter badius & $\mathrm{R}$ & LC \\
\hline & $\begin{array}{l}\text { Order- Galliformes } \\
\text { Family- Phasianidae }\end{array}$ & & & \\
\hline \multirow[t]{2}{*}{5} & Indian Peafowl & Pavo cristatus & $\mathrm{R}$ & LC \\
\hline & $\begin{array}{l}\text { Order- Gruiformes } \\
\text { Family- Rallidae } \\
\end{array}$ & & & \\
\hline \multirow[t]{2}{*}{6} & White-breasted Waterhen & Amaurornis phoenicurus & $\mathrm{R}$ & LC \\
\hline & $\begin{array}{l}\text { Order- Charadriiformes } \\
\text { Family- Charadriidae }\end{array}$ & & & \\
\hline \multirow[t]{2}{*}{7} & Red-wattled Lapwing & Vanellus indicus & $\mathrm{R}$ & $\mathrm{LC}$ \\
\hline & $\begin{array}{l}\text { Order- Columbiformes } \\
\text { Family- Columbidae }\end{array}$ & & & \\
\hline 8 & Blue Rock Pigeon & Columba livia & $\mathrm{R}$ & $\mathrm{LC}$ \\
\hline \multirow[t]{2}{*}{9} & Little Brown Dove & Streptopelia senegalensis & $\mathrm{R}$ & LC \\
\hline & $\begin{array}{l}\text { Order- Psittaciformes } \\
\text { Family- Psittacidae }\end{array}$ & & & LC \\
\hline 10 & Rose-ringed Parakeet & Psittacula krameri & $\mathrm{R}$ & LC \\
\hline \multirow[t]{2}{*}{11} & Alexandrine Parakeet & Psittacula eupatria & $\mathrm{R}$ & NT \\
\hline & $\begin{array}{l}\text { Order- Cuculiformes } \\
\text { Family- Cuculidae }\end{array}$ & & & \\
\hline 12 & Asian Koel & Eudynamys scolopaceus & $\mathrm{R}$ & LC \\
\hline
\end{tabular}




\begin{tabular}{|c|c|c|c|c|}
\hline & Family- Centropodidae & & & \\
\hline \multirow[t]{2}{*}{13} & Greater Coucal & Centropus sinensis & $\mathrm{R}$ & $\mathrm{LC}$ \\
\hline & $\begin{array}{l}\text { Order- Strigiformes } \\
\text { Family- Strigidae }\end{array}$ & & & \\
\hline \multirow[t]{2}{*}{14} & Spotted Owlet & Athene brama & $\mathrm{R}$ & $\mathrm{LC}$ \\
\hline & $\begin{array}{l}\text { Order- Apodiformes } \\
\text { Family- Apodidae }\end{array}$ & & & \\
\hline \multirow[t]{2}{*}{15} & Little Swift & Apus affinis & $\mathrm{R}$ & $\mathrm{LC}$ \\
\hline & $\begin{array}{l}\text { Order- Coraciiformes } \\
\text { Family- Halcyonidae }\end{array}$ & & & \\
\hline \multirow[t]{2}{*}{16} & White-throated Kingfisher & Halcyon smyrnensis & $\mathrm{R}$ & $\mathrm{LC}$ \\
\hline & Family- Meropidae & & & \\
\hline \multirow[t]{2}{*}{17} & Green Bee-Eater & Merops orientalis & $\mathrm{R}$ & $\mathrm{LC}$ \\
\hline & $\begin{array}{l}\text { Order- Bucerotiformes } \\
\text { Family- Bucerotidae }\end{array}$ & & & \\
\hline \multirow[t]{2}{*}{18} & Indian Grey Hornbill & Ocyceros birostris & $\mathrm{R}$ & $\mathrm{LC}$ \\
\hline & $\begin{array}{l}\text { Order- Piciformes } \\
\text { Family- Megalaimidae }\end{array}$ & & & \\
\hline \multirow[t]{2}{*}{19} & Coppersmith Barbet & Megalaima haemacephala & $\mathrm{R}$ & $\mathrm{LC}$ \\
\hline & $\begin{array}{l}\text { Order- Passeriformes } \\
\text { Family- Hirundinidae }\end{array}$ & & & \\
\hline \multirow[t]{2}{*}{20} & Dusky Crag-Martin & Hirundo concolor & $\mathrm{R}$ & $\mathrm{LC}$ \\
\hline & Family- Oriolidae & & & \\
\hline \multirow[t]{2}{*}{21} & Indian Golden Oriole & Oriolous oriolus & $\mathrm{R}$ & $\mathrm{LC}$ \\
\hline & Family- Dicuridae & & & \\
\hline 22 & Black Drongo & Dicrurus macrocercus & $\mathrm{R}$ & $\mathrm{LC}$ \\
\hline \multirow[t]{2}{*}{23} & Ashy Drongo & Dicrurus leucophaeus & WV & $\mathrm{LC}$ \\
\hline & Family- Sturnidae & & & \\
\hline \multirow[t]{2}{*}{24} & Common Myna & Acridotheres tristis & $\mathrm{R}$ & $\mathrm{LC}$ \\
\hline & Family- Corvidae & & & \\
\hline 25 & Rufous Treepie & Dendrocitta vagabunda & $\mathrm{R}$ & $\mathrm{LC}$ \\
\hline \multirow[t]{2}{*}{26} & Jungle Crow & Corvus macrorhynchos & $\mathrm{R}$ & $\mathrm{LC}$ \\
\hline & Family- Irenidae & & & \\
\hline \multirow[t]{2}{*}{27} & Common Iora & Aegithina tiphia & $\mathrm{R}$ & $\mathrm{LC}$ \\
\hline & Family- Pycnonotidae & & & \\
\hline \multirow[t]{2}{*}{28} & Red-vented Bulbul & Pycnonotus cafer & $\mathrm{R}$ & $\mathrm{LC}$ \\
\hline & Family- Leiothrichidae & & & \\
\hline \multirow[t]{2}{*}{29} & Jungle Babbler & Turdoides straitus & $\mathrm{R}$ & $\mathrm{LC}$ \\
\hline & Family- Muscicapidae & & & \\
\hline 30 & Taiga Flycatcher & Ficedula albicilla & WV & $\mathrm{LC}$ \\
\hline 31 & Red-breasted Flycatcher & Ficedula parva & WV & $\mathrm{LC}$ \\
\hline 32 & Tickell's Blue Flycatcher & Cyornis tickelliae & $\mathrm{R}$ & $\mathrm{LC}$ \\
\hline 33 & Grey-headed Canary Flycatcher & Culicicapa ceylonensis & WV & $\mathrm{LC}$ \\
\hline 34 & Oriental Magpie Robin & Copsychus saularis & $\mathrm{R}$ & $\mathrm{LC}$ \\
\hline 35 & Black Redstart & Phoenicurus ochruros & WV & $\mathrm{LC}$ \\
\hline \multirow[t]{2}{*}{36} & Indian Robin & Copsychus fulicatus & $\mathrm{R}$ & $\mathrm{LC}$ \\
\hline & Family- Rhipiduridae & & & \\
\hline \multirow[t]{2}{*}{37} & White-spotted Fantail-Flycatcher & Rhipidura albogularis & $\mathrm{R}$ & $\mathrm{LC}$ \\
\hline & Family- Cisticolidae & & & \\
\hline 38 & Ashy Prinia & Prinia socialis & $\mathrm{R}$ & $\mathrm{LC}$ \\
\hline \multirow[t]{2}{*}{39} & Common Tailorbird & Orthotomus sutorius & $\mathrm{R}$ & $\mathrm{LC}$ \\
\hline & Family-Slyviidae & & & \\
\hline 40 & Sulphur-bellied Warbler & Phylloscopus griseolus & WV & LC \\
\hline 41 & Greenish Warbler & Phylloscopus trochiloides & WV & LC \\
\hline
\end{tabular}




\begin{tabular}{|l|l|l|l|l|}
\hline 42 & Lesser Whitethroat Warbler & Sylvia curruca & WV & LC \\
\hline & Family- Dicaeidae & & & \\
\hline 43 & Thick-billed Flowerpecker & Dicaeum agile & R & LC \\
\hline 44 & Tickell's Flowerpecker & Dicaeum erythrorhyncos & R & LC \\
\hline & Family- Nectariniidae & & & \\
\hline 45 & Purple-rumped Sunbird & Nectarinia zeylonica & R & LC \\
\hline 46 & Purple Sunbird & Cinnyris asiaticus & R & LC \\
\hline & Family- Zosteropidae & & & \\
\hline 47 & Oriental White-Eye & Zosterops palpebrosa & R & LC \\
\hline & Family- Passeridae & & & \\
\hline 48 & House Sparrow & Passer domesticus & R & LC \\
\hline & Family- Estrildidae & & & \\
\hline 49 & Indian Silverbill & Lonchura malabarica & R & LC \\
\hline & Family- Motacillidae & & & \\
\hline 50 & Yellow Wagtail & Motacilla flava & WV & LC \\
\hline 51 & White Wagtail & Motacilla alba & WV & LC \\
\hline
\end{tabular}

R- Resident, WV- Winter Visitor, LC- Least Concerned and NT- Near Threatened.

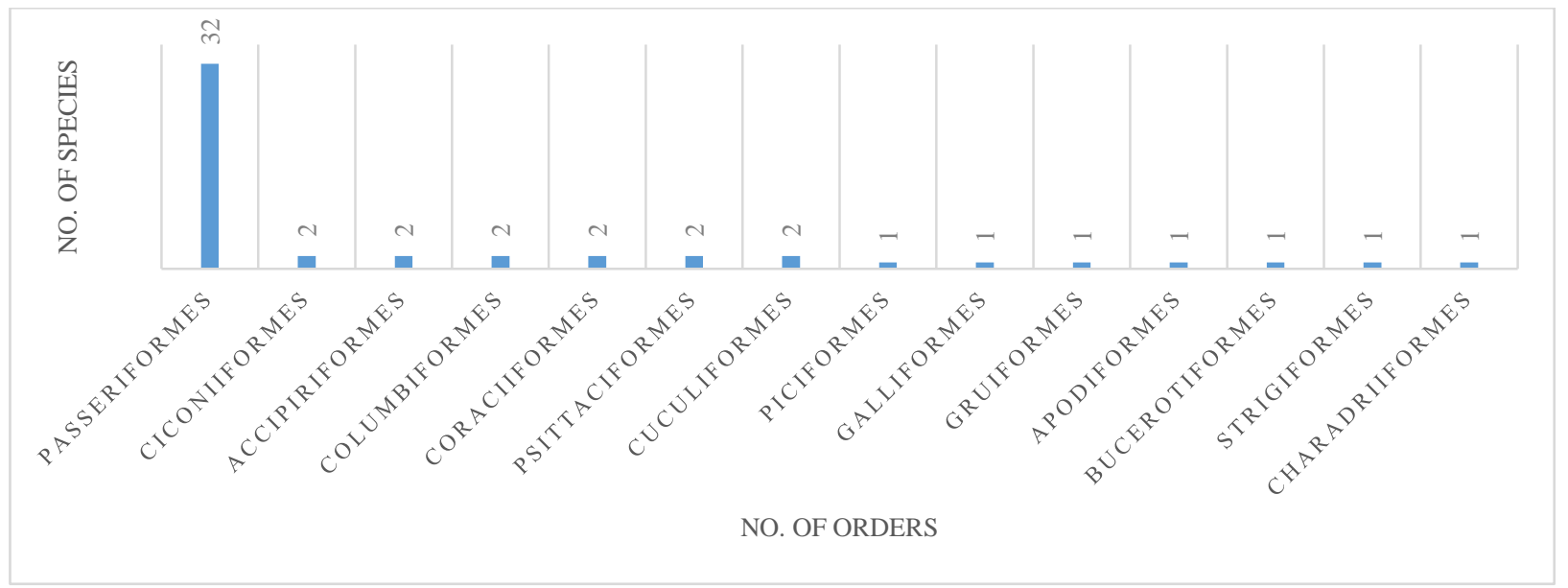

Figure 1: Order wise percent contribution of the bird species found at the Govt. Holkar Science College Campus.

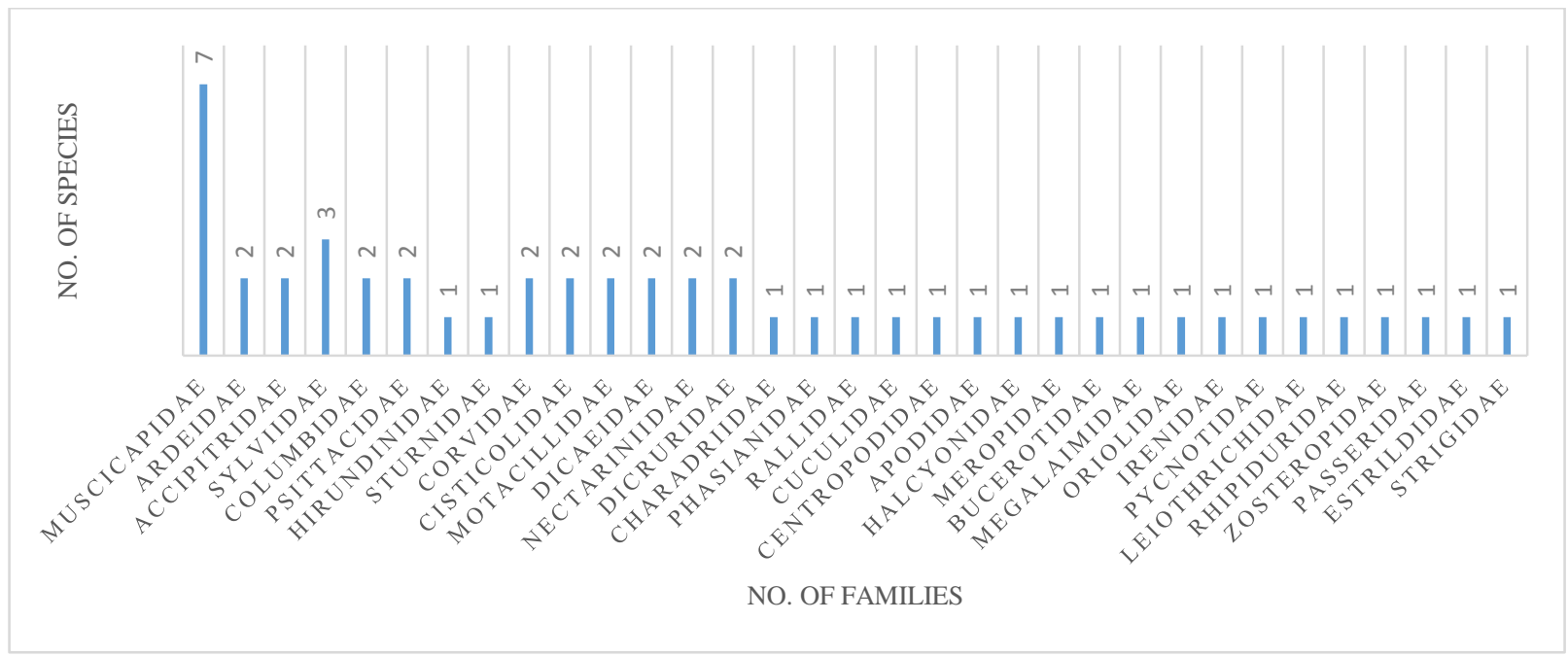

Figure 2: Family wise percent contribution of bird species found at Govt. Holkar Science College Campus. 


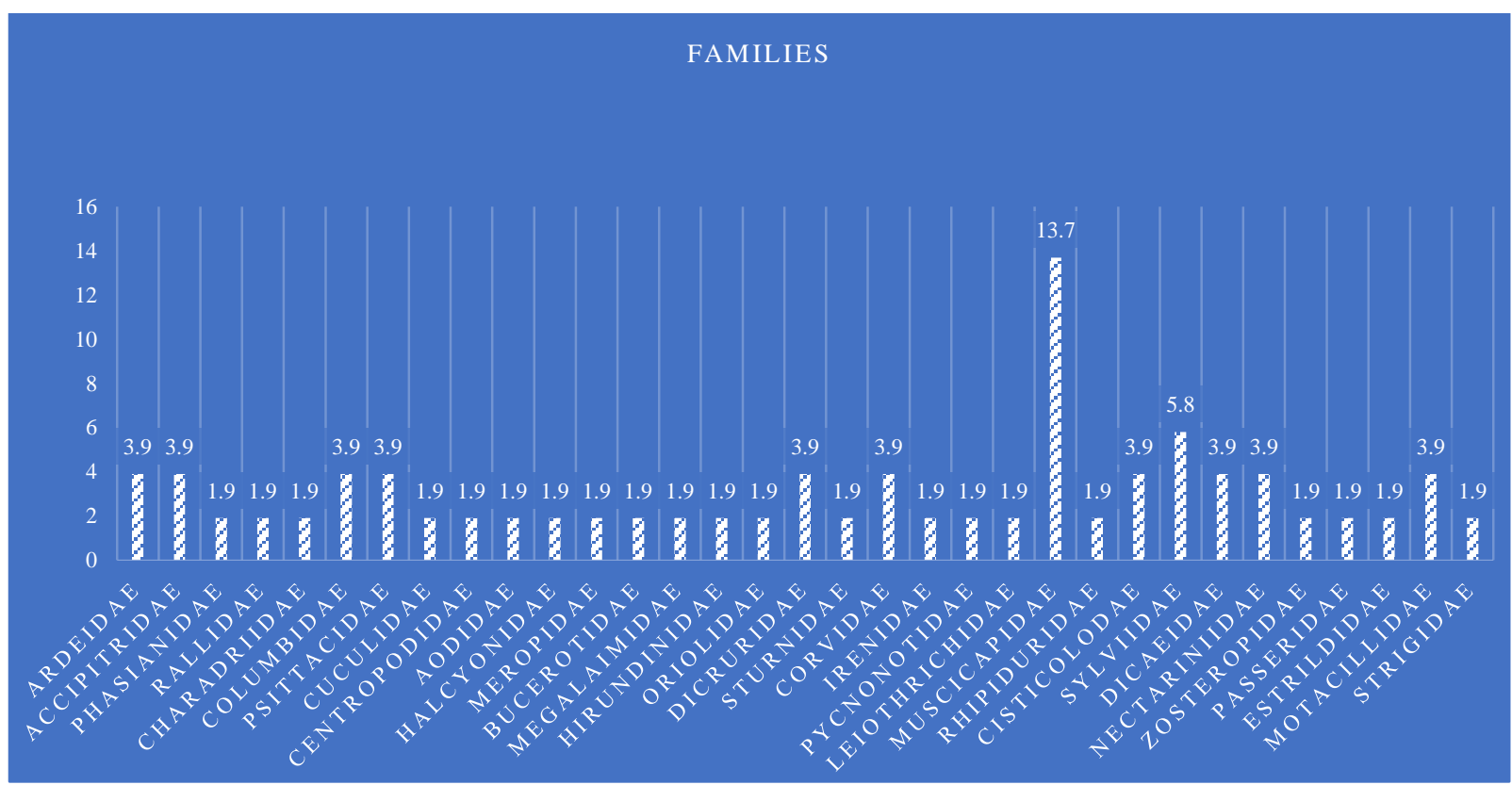

Figure 3: Relative Diversity of Families found at Govt. Holkar Science College, Indore.

Table 2: List of avian fauna breeding at selected site.

\begin{tabular}{|c|c|c|c|c|}
\hline S. No. & Name of Bird Species & $\begin{array}{c}\text { Breeding Recorded } \\
\text { based on }\end{array}$ & $\begin{array}{c}\text { No. of } \\
\text { Nests/Juveniles } \\
\text { Recorded } \\
\end{array}$ & Month \\
\hline 1. & Black Kite & Nest & 1 & March-May \\
\hline 2. & Shikra & , & 1 & April-June \\
\hline 3. & Red-wattled Lapwing &, & 1 & March-May \\
\hline 4. & Blue Rock Pigeon & , & 7 & All Year \\
\hline 5. & Little Brown Dove & , & 1 & March-May \\
\hline 6. & Coppersmith Barbet & , & 3 & April-June \\
\hline 7. & Red-vented Bulbul & , & 2 & March-May \\
\hline 8. & Jungle Babbler & , & 2 & March-July \\
\hline 9. & Oriental Magpie Robin & , & 2 & May-June \\
\hline 10. & Purple Sunbird & , & 2 & March-May \\
\hline 11. & Rose-ringed Parakeet & , & 1 & May-June \\
\hline 12. & Tickell's Flowerpecker & , & 1 & April \\
\hline 13. & Rufous Treepie & Juvenile & 2 & May \\
\hline 14. & Indian Robin & , & 3 & May \\
\hline 15. & Ashy Prinia & , & 3 & September \\
\hline 16. & Thick-billed Flowerpecker & , & 1 & May \\
\hline 17. & Spotted Owlet & Copulating & ---- & May \\
\hline
\end{tabular}


Table 3: List of Plant/Tree used, Nesting material used and Nest type.

\begin{tabular}{|c|c|c|c|c|}
\hline S. No. & Name of Bird & $\begin{array}{l}\text { Name of Plant or Tree } \\
\text { or Site }\end{array}$ & Nesting Materials & Nest Type \\
\hline 1. & Black Kite & $\begin{array}{l}\text { Eucalyptus Tree } \\
\text { (E. tereticornis) }\end{array}$ & $\begin{array}{l}\text { Small branches, sticks, } \\
\text { twigs, rope, cloth, and } \\
\text { plastic string }\end{array}$ & Platform Nest \\
\hline 2. & Shikra & $\begin{array}{l}\text { Eucalyptus Tree } \\
\text { (E. tereticornis) }\end{array}$ & Sticks (small \& big) & ", \\
\hline 3. & Blue Rock Pigeon & $\begin{array}{l}\text { Wall hole, ceiling, tin } \\
\text { shade }\end{array}$ & Small sticks & , \\
\hline 4. & Little Brown Dove & Iron Rod of Tin Shade & Small sticks, twigs, grass & , \\
\hline 5. & Rose-ringed Parakeet & $\begin{array}{l}\text { Eucalyptus Tree } \\
\text { (E. tereticornis) }\end{array}$ & ----- & Hole Nest \\
\hline 6. & Coppersmith Barbet & $\begin{array}{l}\text {-Peepal Tree } \\
\text { (F. religiosa) } \\
\text {-Babul Tree } \\
\text { (V. nilotica) } \\
\text {-Mango Tree } \\
\text { (M. indica) }\end{array}$ & ----- & $"$ \\
\hline 7. & Oriental Magpie Robin & $\begin{array}{l}\text {-Eucalyptus Tree } \\
\text { (E. tereticornis) Cavity } \\
\text { - Hole in the wall behind } \\
\text { Botany Department }\end{array}$ & Grass twigs, fibres & $"$ \\
\hline 8. & Red-vented Bulbul & $\begin{array}{l}\text {-False Ashoka Tree } \\
\text { (P. longifolia) } \\
\text { - Tubelight Frame in } \\
\text { Zoology Department }\end{array}$ & Grass, fibres, cobweb & Cup Nest \\
\hline 9. & Jungle Babbler & $\begin{array}{l}\text {-Cuban Royal Palm } \\
\text { (R. regia) } \\
\text {-Neem Tree (A. indica) }\end{array}$ & $\begin{array}{l}\text { Twigs, fibres, plastic } \\
\text { string }\end{array}$ & $"$ \\
\hline 10. & Purple Sunbird & $\begin{array}{l}\text {-China Rose Plant } \\
\text { (H. rosa) } \\
\text {-Fencing wire } \\
\text {-Babul Tree } \\
\text { (V. nilotica) }\end{array}$ & $\begin{array}{c}\text { Grass, fibres, cobweb, } \\
\text { leaves }\end{array}$ & Pendant Nest \\
\hline 11. & Tickell's Flowerpecker & Mango Tree $(M$. indica $)$ & $\begin{array}{c}\text { Grass, fibers, cotton and } \\
\text { cobweb }\end{array}$ & $"$ \\
\hline 12. & Red-wattled Lapwing & Open bare ground & Lined with small pebbles & Ground Nest \\
\hline
\end{tabular}

A- Including Resident and Winter Migratory Species

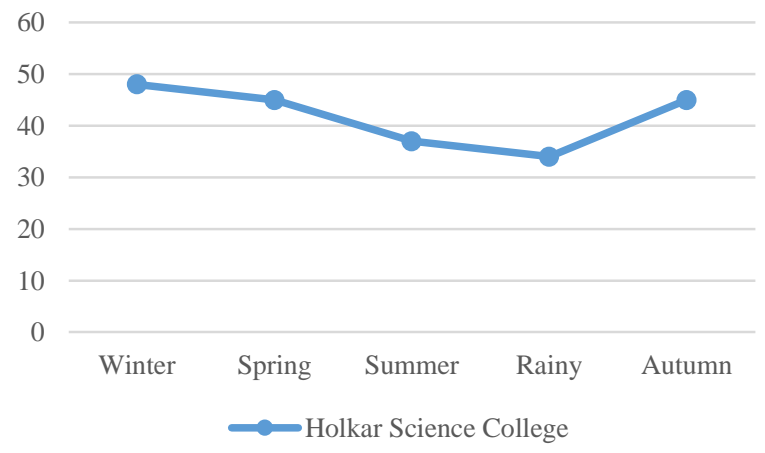

B- Only Resident Species

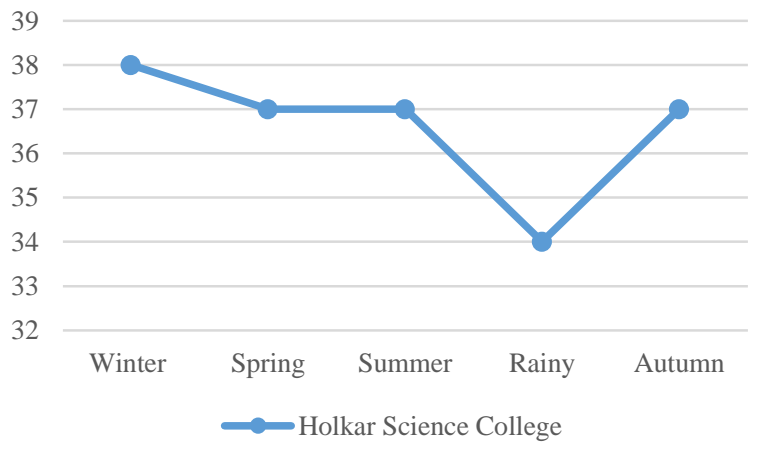

Figure 4: Seasonal Variation of Avian Fauna (A- Both Resident and Migratory species, B- Only Resident Species) 


\section{CONCLUSION AND FUTURE SCOPE}

The present study highlights the identification, breeding and seasonal variation of the avian fauna and also a thorough review of prior available related literature. During the study period, the college campus was found to support fifty one species of birds in different seasons. Interestingly, the study identified thirteen new, previously unrecorded species of birds, at the Govt. Holkar science college campus. The study site which serve as a breeding ground for seventeen species of birds, reflects it's good ecological health, as breeding is a strong bio-indicator for any environment. The investigation indicates that, this is the first ever record of breeding of selective birds from the college campus. Although most of the bird species were resident to this area, but the thorough review of the past related literature of this area has highlighted some variations in seasonal occurrences of previously studied selective bird species. The varying diversity of identified bird species reflects excellent bird adaptability to the urban green spaces and importance of these in bird conservation. Mature trees with dense foliage and natural cavities in the campus, attracts several species of birds. Negative impact on bird existence was seen in the form of unwanted human interference and menace of stray animals, which is an existing threat to bird survival and sustenance and needs immediate attention. Based on the current study, it can be concluded that the college campus is in good ecological health. Although, proper maintenance of gardens and some enrichment at the college is required to conserve its inhabitants.

\section{ACKNOWLEDGMENT}

The authors are grateful to Dr. M.M.P Shrivastava, Professor and H.OD. of Zoology, Govt. (Model, Autonomous) Holkar Science College, Indore (M.P.) for his immense support and guidance in the completion of the research work. We express our sincere thanks to honorable Principal, Govt. Holkar Science College, Indore for providing the facilities and granting permission to carry out research work.

\section{FEW PHOTOGRAPHS OF AVIAN FAUNA IDENTIFIED AT THE STUDY SITE:}

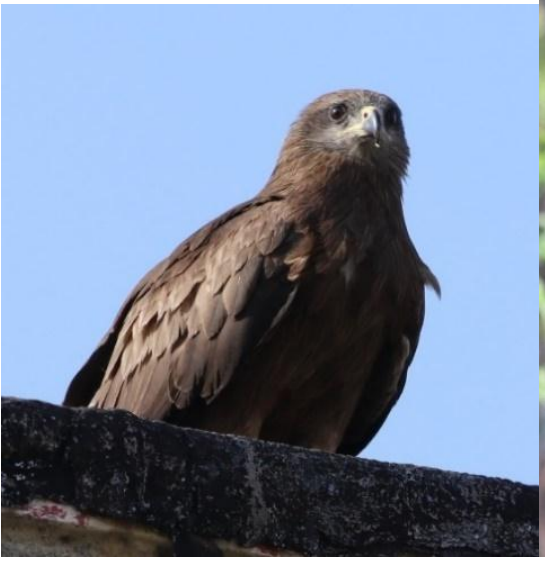

Black Kite

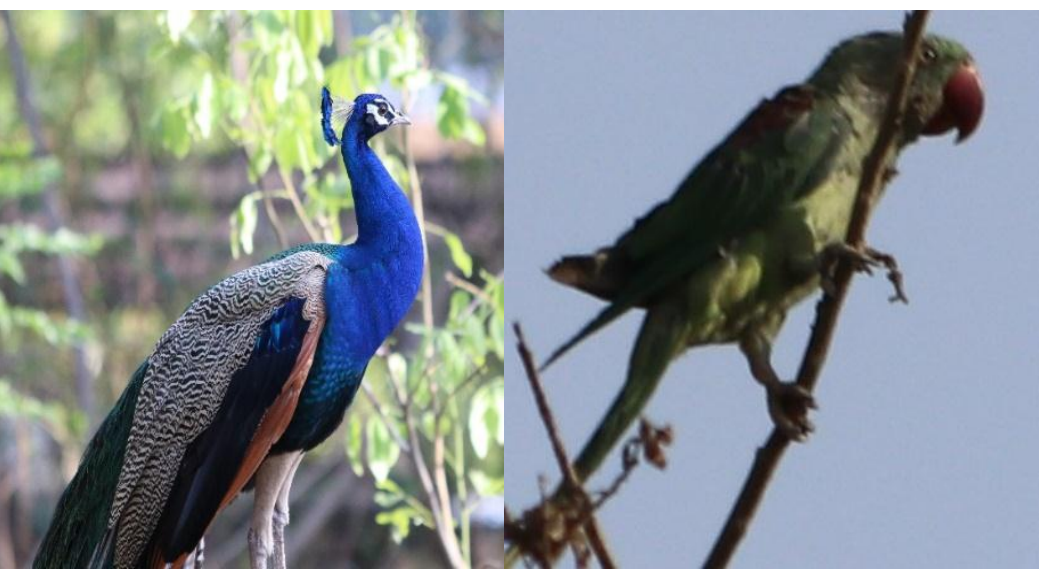

Indian Peafowl
Alexandrine Parakeet
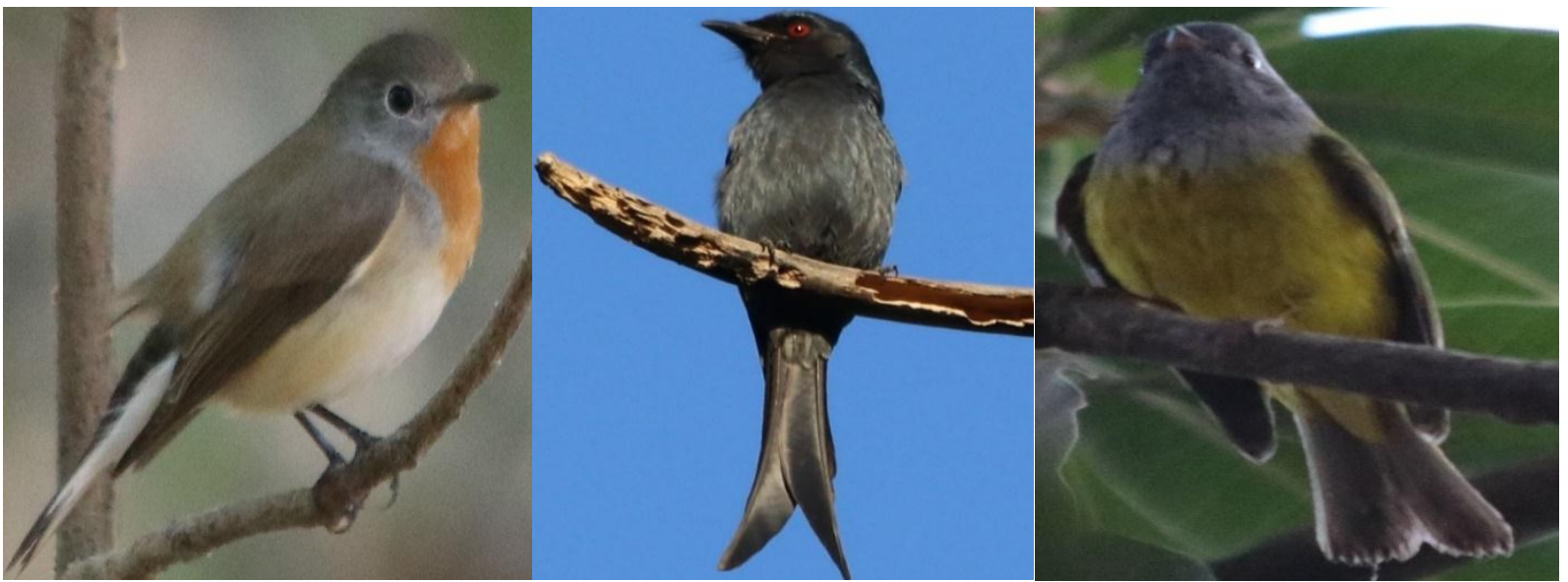

Red-breasted Flycatcher

Ashy Drongo

Grey-headed Canary Flycatcher 


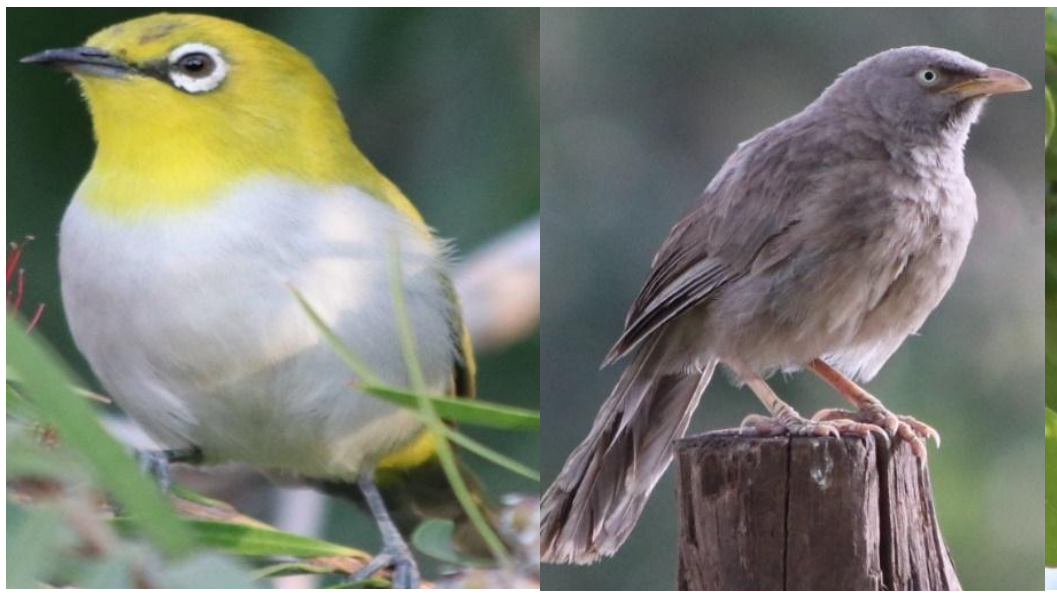

Oriental White-Eye
Jungle Babbler

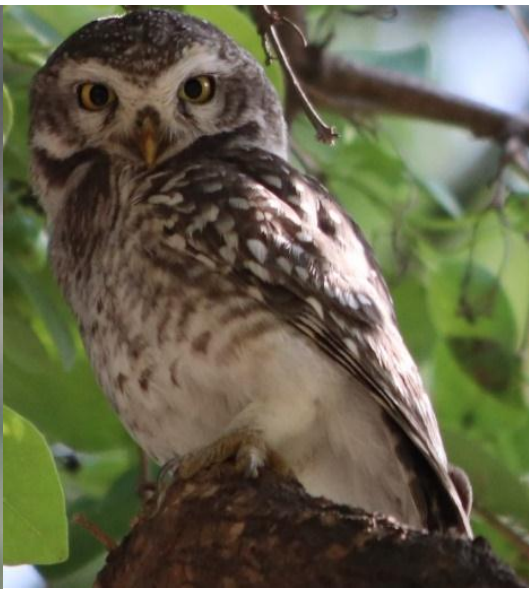

Spotted Owlet

Plate- 1

\section{REFE RENCES}

[1]. S. Ali, "The Book of Indian Birds (Revised 13 ${ }^{\text {th }}$ Ed).", Bombay Natural History Society. Oxford University Press, New Delhi, pp.1326, 2002.

[2]. P. Koskimies, "Birds as a tool in environmental monitoring", Annales Zoologici Fennici, Vol. 26, pp.153-166, 1989

[3]. N. Mariappan, B.K. Ahamed Kalfan, S. Krishnakumar, "Assessment of Bird Population in Different Habitats of Agricultural Ecosystem", International Journal of Scientific Research in Environmental Sciences (IJSRES), Vol. 1, Issue.11, pp.306-316, 2013.

[4]. M. Dhindsa, H.K. Saini, "Agricultural Ornithology: An Indian Perspective", Journal of Biosciences, Vol. 19, No.4, pp.391-402, 1994.

[5]. S.K. Panwar, P.S. Salunkhe, "Study of Migratory Birds in and around Pandharpur city with special reference to Takali (Padmawati) lake, Pandharpur, Dist. Solapur (M.S.)", AvishkarSolapur University Journal, Vol. 3, pp.38-44, 2014.

[6]. R.G. Davies, O. Barbosa, R.A. Fuller, J. Tratalos, N. Burke, D. Lewis, P.H. Warren, K.J. Gaston, "City-wide relationships between green spaces, urban land use and topography", Urban Ecosystems, Vol. 11, pp.269-287, 2008.

[7]. R.A. Fuller, P.H. Warren, K.J. Gaston, "Day time noise predicts nocturnal singing in urban robins", Biology letters, Vol. 3, pp.368370, 2007.

[8]. S.R. Loss, M.O. Ruiz, J.D. Brawn, "Relationships between avian diversity, neighborhood age, income and environmental characteristics of an urban landscape", Biological Conservation, Vol. 142, pp.2578-2585, 2009.

[9]. U.G. Sandström, P. Angelstam, G. Mikusinski, "Ecological diversity of birds in relation to the structure of urban green space", Landscape and Urban Planning, Vol. 77, pp.39-53, 2006.

[10]. M. Menon, P. Devi, R. Mohanraj, "Functional Assemblages of Birds in Heterogeneous Landscapes along an Urban-Rural Gradient in Tiruchirappalli, India", Journal of the Bombay Natural History Society, Vol. 109, Issue.1\&2, pp.23-29, 2012.

[11]. M.M. Prakash, K. Panwar, M. Malhotra, V.K. Sharma, P. Kaskhedikar, A. Sharma, N.K. Dhakad, "Birds of Holkar Science College Campus, Indore", Troiectory, Vol. 12, No.1, pp.59-63, 2004.

[12]. K. Pawar, R.K. Alone, M.M. Prakash, "A study of butterfly diversity and distribution at Holkar Science College Campus
Indore, India", South Indian Journal of Biological Sciences, Vol. 3, No.1, pp.27-32, 2017.

[13]. R. Grimmett, C. Inskipp, R. Inskipp, "Birds of Indian Subcontinent. (2 ${ }^{\text {nd }}$ Ed.)", Oxford University Press, London. pp.1$528,2011$.

[14]. B. Grewal, S. Sen, S. Singh, N. Devasar, G. Bhatia, "A pictorial field guide to Birds of India", Om Books International, Noida. pp.1791, 2016.

[15]. C.J. Bibby, N.D. Burgess, D.A. Hill, "Bird Census Techniques", Academic Press, London, pp.120-121, 2012.

[16]. M. Datta, "Status, guild and diversity of avian fauna from a wetland site and surroundings, in krishnagar, a city beside tropic of cancer, West Bengal, India", International Journal of Fauna and Biological Studies, Vol. 3, Issue.4, pp.68-75, 2016.

[17]. P. Bhadja, A.K. Vaghela, "Study on Avifaunal diversity from Two Freshwater Reservoir of Rajkot, Gujarat, India", International Journal of Research in Zoology, Vol. 3, Issue.2, pp.16-20, 2013.

[18]. S. Kushwaha, A. Kanaujia, A. Kumar, A. Kumar, S. Kumar, "Avifaunal diversity of Tikamgarh District, Madhya Pradesh, India", Discovery Nature- The International Monthly Journal, Vol. 9, No.20, pp.20-32, 2015.

[19]. K. Chandra, S.K. Dutta, R.P. Gupta, A. Raha, "Diversity and Conservational Status of Avifauna in Bastar Plateau of Chhattisgarh, India", Ambient Science, Vol. 2, Issue.1, pp.31-43, 2015.

[20]. A.M. Chilke, "Avian Diversity in and around Bamanwada Lake of Rajura, District-Chandrapur (Maharashtra)", Annals of Biological Research, Vol. 3, Issue.4, pp.2014-2018, 2012.

[21]. S. Sharma, A. Shukla, "Preliminary study on Avian Faunal Diversity of Polipathar area in Jabalpur (M.P.)", International Journal of Current Advanced Research, Vol. 4, Issue.9, pp.364-367, 2015.

[22]. N. Bagde, "Avian Diversity and its Conservation in West Chhindwara Region of Madhya Pradesh, India", International Journal of Life Sciences, Vol. 3, Issue.3, pp.210-218, 2015.

[23]. R. Rawal, S. Gaherwal, N. Wast, "Avian diversity in and around Kunda reservoir, (District-Dhar)", International Journal of Advanced Research, Vol. 4, Issue.1, pp.690-695, 2016.

[24]. K. Chandra, R.K. Singh, "Avifauna of Madhya Pradesh and Chhattisgarh", Zoo's Print Journal, Vol. 19, No.7, pp.1534-1539, 2004.

[25]. M.S. Mewada, "Ecological study and avifaunal diversity of Narmada River and its surrounding areas of Dindori district, 
(M.P.)", International Journal of Scientific Research in Biological Sciences, Vol. 4, Issue.1, pp.4-9, 2017.

[26]. A.D. Tiple, N. Kulkarni, S. Paunikar, K.C. Joshi, "Avifauna of Tropical Forest Research Institute Campus, Jabalpur, Madhya Pradesh, India", Indian Journal of Tropical Biodiversity, Vol. 18, Issue.1, pp.133-141, 2010.

[27]. A. Aggarwal, G. Tiwari, S. Harsh, "Avian diversity and density estimation of birds of the Indian Institute of Forest Management Campus, Bhopal India", Journal of Threatened Taxa, Vol. 7, No.2, pp.6891-6902, 2015.

[28]. A.M. Ali Samsoor, S. Asokan, R. Manikannan, P. Radhakrishnan, "Checklist and nesting patterns of avifauna in and around Mayiladuthurai region, Tamil Nadu, India", Journal of Threatened Taxa, Vol. 3, No.6, pp.1842-1850, 2011.

[29]. S. Kaur, K.S. Khera, "Nesting and Egg laying of Common Myna in Agricultural Landscape", Indian Journal of Applied Research, Vol. 4, Issue.2, pp.31-33, 2014.

[30]. S. Suárez, J. Balbontín, M. Ferrer, "Nesting habitat selection by Booted Eagles (Hieraaetuspennatus) and implications for management", Journal of Applied Ecology, Vol. 37, pp.215-223, 2000.

[31]. A. Shivprakash, K.R. Das Kishen, T. Shivanand, T. Girija, A. Sharath, "Notes on the breeding of the Indian Spotted Eagle (Aquila hastate)", Indian Birds, Vol.No.1, pp.2-4, 2006.

[32]. S.C. Rottenborn, "Nest-site selection and reproductive success of urban Red-shouldered Hawk in Central California", Journal of Raptor Research, Vol. 34, Issue.1, pp.18-25, 2000.

[33]. T.K. Kaushik, R.C. Gupta, "Black Kite populations are suffering declining trends in Kurukshetra and likely to experience further depletion- An analysis of Causes", The Journal of Tropical Life Sciences, Vol. 4, No.1, pp.14-18, 2014.

[34]. D. Radhamany, K.S.A. Das, P.A. Azeez, L. Wen, L.K. Sreekala, "Usage of Nest materials by House Sparrow (Passer domesticus) along an Urban to Rural Gradient in Coimbatore, India", Tropical Life Science Research, Vol. 27, No.2, pp.127-134, 2016.

[35]. R.K. Garg, R.J. Rao, D.N. Saksena, "Spatial relations of migratory birds and water quality management of Ramsagar reservoir, Datia, Madhya Pradesh, India", Journal of Ecology and the Natural Environment, Vol. 5, No.10, pp.335-339, 2013.

[36]. A. Jain, L.K. Mudgal, G.D. Sharma, "Spatial Relations of Migratory Birds and Water Quality Management of Sirpur Lake, Indore, Madhya Pradesh", International Journal of Scientific Research and Education, Vol. 3, Issue.7, pp.4091-4096, 2015.

[37]. P. Joshi, V.K. Shrivastava, "Ecological study and bird diversity of Tawa Reservoir and its surrounding areas of Hoshangabad district (Madhya Pradesh)", The Bioscan: An International Quarterly Journal of Life Sciences, Vol. 7, No.1, pp.129-133, 2012.

[38]. B.R. Varma, K.C. Gupta, M.M. Prakash, T.P.S Chauhan, "A Preliminary Report on the Birds of Vidya Vihar", Journal of Jiwaji University, Vol. 6, No.2, pp.136-142, 1978.

[39]. B.E. Lenth, R.L. Knight, M.E. Brennan, "The effects of dogs on wildlife communities", Natural Areas Journal, Vol. 28, Issue.3, pp.218-227, 2008.

[40]. J.K. Young, K.A. Olson, R.P. Reading, S. Amgalanbaatar, J. Berger, "Is wildlife going to the dogs? Impacts of Feral and Freeroaming dogs on Wildlife Populations", BioScience, Vol. 61, Issue.2, pp.125-132, 2011. 